\title{
Multiple Osteocartilaginious Exostosis in a Developing community
}

\author{
Wilson Onuigbo* \\ Department of Pathology, Medical Foundation \& Clinic, Nigeria
}

Submission: December 08, 2017; Published: January 03, 2018

"Correspondence Address: Wilson Onuigbo, Department of Pathology, Medical Foundation \& Clinic, 8 Nsukka Lane, Enugu 400001, Nigeria, Email: wilson.onuigbo@gmail.com

\section{Abstract}

Jaffe's standard work on bone tumors did define multiple osteocartilaginious exostosis as the hereditary form of the solitary type. However, in a developing community, the family tree may not be traceable. The relatively few cases encountered among the Ibo/Igbo ethnic group in the South Eastern Region of Nigeria are worthy of documentation.

Keywords: Bone; Tumor; Exostosis; Multiple, Osteocartilaginous; Age

\section{Introduction}

In his standard work on bone tumors, interest was shown not only on solitary but also on familial multiple osteocartilaginious exostosis by Jaffe [1]. As for the latter, the element of familiar disposition is difficult to trace in a developing community. Accordingly, this paper beams on the few cases provided that multiplicity occurred. This has been aided by the injunction that the establishment of a histopathology data pool facilitates epidemiological analysis [2]. The pool long established at Enugu, in South Eastern Nigeria, offers itself for such analysis [3]. The analysis is in Tabular form.

\section{Results}

Table 1: Age, sex, sites.

\begin{tabular}{|c|c|c|c|c|}
\hline No & Initials & Age & Sex & Sites \\
\hline 1 & OE & 14 & M & All 4 limbs \\
\hline 2 & EN & 10 & F & Multiple in legs and hands \\
\hline 3 & IS & 11 & F & Multiple both upper legs \\
\hline 4 & UV & 6 & M & Multiple long bones, scapular, ribs \\
\hline 5 & CO & 14 & F & Left humerus, left elbow, R tibia \\
\hline 6 & NK & 12 & F & Multiple \\
\hline
\end{tabular}

Table 1 on the whole, the patients were aged from 6 to 14 years (mean 11 years). The female/male ratio was 2:1. Multiplicity of sites was striking. The specimens measured $1 \mathrm{~cm}$ to $3 \mathrm{~cm}$. Incidentally, only two patients were X-Rayed

\section{Discussion}

A Norfolk, USA, group stated that these exostoses are uncommon in the hand [4]. There were 2 examples here. In a French book [5], these exostoses were commonest in males. This is contrary to my experience. From the Netherlands [6], these tumors are mostly formed along the long bones of the extremities. The present series is of this distribution. Unlike the local childhood cases, a USA 54-year-old male was presented twice curiously [7].

\section{References}

1. Jaffe HL (1958) Tumors and timorous conditions of the bones and joints. Lea \& Febiger, Philadelphia, USA, pp. 150.

2. Macartney JC, Rollaston TP, Codling BW (1980) Use of a histopathology data pool for epidemiological analysis. J Clin Pathol 33(4): 351-353.

3. Basden GT (1966) Niger Ibos. Cass, London, UK.

4. Karr MA, Aulicino PL, Dupuy TE, Gwathmey FW (1984) Osteochondromas of the hand in hereditary multiple exostosis: Report of a case presenting as a blocked proximal interphalangeal joint. J Hand Surg 9(2): 264-268.

5. Mazabraud A (2008) Osteogenic Exostosis (Osteochondroma), Multiple Exotoses, Subungual Exostosis, Metachondromatosis. Pathology of Bone Tumours, Heidelberg: Springer-Verlag Berlin H p. 63-75.

6. Bovee JV (2008) Multiple osteochondromas. Orphan J Rare Dis 3:3.

7. Shtomakher G, Kaufman MA, Bhoola PH, Patel AA, Rice SM, et al. (2015) Multiple osteocartilaginious exostoses of the lower extremity: A case report. Foot 25(1): 62-65. 
Your next submission with Juniper Publishers will reach you the below assets

- Quality Editorial service

- Swift Peer Review

- Reprints availability

- E-prints Service

- Manuscript Podcast for convenient understanding

- Global attainment for your research

- Manuscript accessibility in different formats

( Pdf, E-pub, Full Text, Audio)

- Unceasing customer service

Track the below URL for one-step submission https://juniperpublishers.com/online-submission.php 